\title{
¿La estética nos socializará?
}

\author{
María Rosa Palazón Mayoral
}

\author{
Para Adolfo Sánchez Vázquez \\ In memoriam
}

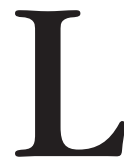

a Universidad Autónoma Metropolitana y la Asociación Filosófica de México me invitaron a las mesas redondas en honor de mi profesordoctor -categoría más alta en España- Adolfo Sánchez Vázquez, a cuyo Seminario de Estética asistí, junto con Gabriel Vargas Lozano, tal friolera de años que he olvidado la cantidad: le fuimos, Gabriel y yo, y otro montón, discípulos fieles: nosotros dos no fallamos a ninguno de sus cursos, y Tánatos ha decidido que ese seminario mantenga la misma edad para siempre. ¿Cómo no admirar y amar a don Adolfo, si mostró sin ningún balbuceo, una tendencia libertaria en sus textos y en su praxis, la que llevó a término en las aulas.

Su coherencia. Su coherencia dice que, siendo perseguido por el fascismo, vino a refugiarse en nuestra tierra y acabó teniendo dos patrias, porque supo que lo importante no es estar en uno u otro lado del mundo, sino cómo se está. Y ¿cómo estuvo? Que responda Miguel Hernández con "El silbo vulnerado”: "[...] hay ruiseñores que cantan encima de los fusiles y en medio de las batallas". En esta ocasión no los aburriré con tantas cosas que dije en las ocasiones anteriores, sino que daré una visión sesgada de dos excelentes libros de estética, disciplina en la que marcó una frontera que expulsó de la ignorancia supina, y como tal arrogante, a quienes la trataban como una "bella manera de perder el tiempo". A condición de establecer un diálogo a fondo con Cuestiones estéticas y artísticas contemporáneas ${ }^{1}$ y con De la estética de la recepción a la estética de la participación,$^{2}$ ahora sólo deseo invitar a la lectura de estos magníficos textos. Dividido uno en las dos temáticas que indica el título; y el otro, en las conferencias que dictó en 2004 sobre la primera corriente

${ }^{1}$ Adolfo Sánchez Vázquez, Cuestiones estéticas contemporáneas. México, FCE, 1996.

${ }^{2}$ A. Sánchez Vázquez, De la estética de la recepción a una estética de la participación. Pról. de Ambrosio Velasco. México, unAm, Facultad de Filosofía y Letras, 2005. 
de pensamiento - la recepción- y sobre la toma de partido socializante que mi maestro tomó a partir de las polémicas de los años sesentas. En el primer caso, se negó a corregir las teorías con que ya no comulgaba, dejando a los lectores la última palabra.

Las ofertas de ambos libros son satisfactorias para los interesados en la estética o filosofía de la sensibilidad, que se ocupa de manera privilegiada de las artes. La literatura, según el punto de vista de mi maestro, a partir de la Crítica del gusto de Galvano Della Volpe, incide en el campo del conocimiento mediante un plano expresivo - "contextual (vale para esa obra nada más) y orgánico" (inalterable: todo contribuye al resultado). La literatura carga figuras retóricas que, en el caso del símbolo y la metáfora indican uno de nuestros modos de conocer y de explicar los hechos, y un principio de realidad que no se atiene a una presumible correspondencia entre lo narrado y lo acontecido, aunque sí muestra una manera de estar en el mundo (Ricoeur). Complementariamente, Sánchez Vázquez desarrolla la espinosa cuestión "Sobre la verdad en la literatura y las artes", deslindando de los alcances de esta asignación valorativa a la actividad artística autorreferida (la música o un cuadro afigurativo, por ejemplo) en comparación con la referencial que establece, a guisa de ejemplificación, lo que sucedió en una situación histórica mediante personajes y situaciones concretos. Añade en De la estética de la recepción... que siempre existe una interpretación, una hermenéutica, sin la cual la obra no tendría consumo: sería menos que un objeto, porque estos tienen una finalidad. Producción y consumo, dijo Marx y nuestro profesor emérito escribió, en Las ideas estéticas de Marx, son un dúo inseparable: la obra requiere una recepción interpretativa donde asome la ética, porque la hermandad entre ética y estética es original (bonnella abreviado dio bella). Por ejemplo, para Aristóteles la tragedia produce compasión y horror (eleos y phobos): de su comprensión nace la catarsis. La obra de arte no es, va siendo sus actualizaciones históricas (Benjamin).

En Cuestiones estéticas... y en el ensayo sobre Yuri Lotman, Sánchez Vázquez analiza cómo -siguiendo a los formalistas rusos, la lingüística estructural y la teoría de la información-, este miembro de la Escuela de Tartu descubre que la literatura está compuesta de signos que establecen una dependencia tal entre los planos expresivos y de contenido que los mismos elementos que, al entrar en distintas relaciones intratextuales, reciben otras significaciones, y que cualquier elemento, sea un simple nexo gramatical, se vuelve informativo. Asimismo, para Lotman lo que normalmente sería un "ruido" u obstáculo en el proceso comunicativo, si no es tan fuerte que acabe con la obra, se interpreta como información semántica y estética. Por ejemplo, las jarchas en relación con el desaparecido verso mozárabe del que formaban parte, que igual que la falta de brazos de la Venus de Milo son hechos que se toman como enigmas. 
Además, Sánchez Vázquez analiza las aportaciones o "transparencias" de Lotman sobre la especificidad del lenguaje literario y también sus "opacidades" al respecto. El intérprete siempre queda supuesto: el texto es base y fin del análisis. Sin embargo, para quienes sientan inquietud acerca de los compromisos ideológicos que establecen las obras con la sociedad, este festín teórico titulado Cuestiones... se ocupa de los planteamientos de Jean Paul Sastre, José Revueltas y Diego Rivera. Nuestro esteta hispanomexicano distingue al respecto entre ideología general, o del contexto en que ocurre la creación, la ideología del autor, y la ideología dominante en una época y un lugar, que concierne a la experiencia estética, y a qué se considera arte, técnica, creación y las múltiples funciones de estas distintas áreas.

En la línea de Herbert Read, nuestro maestro emérito pondera la educación estética aplicada a las artes, la naturaleza, la técnica y la vida cotidiana, porque ésta despierta la sensibilidad, el sentido comunitario y la capacidad poiética o creativa. Sí, o la educación es estética, o no es. En De la estética de la recepción... nuestro profesor pormenoriza básicamente las teorías de Ingarden, Jauss, Mukarovský y Gadamer, y de paso trata a Paul Valéry.

El paradigma de la estética de la recepción propuesto por Hans Robert Jauss en "La historia de la literatura como provocación a la ciencia literaria" consta de: la relación entre texto y obra; el "horizonte de expectativas" y "la función social de la literatura". Con Iser, Sánchez Vázquez aborda la "determinación de los espacios vacíos" del texto; la indeterminación con Ingarden e Iser; cómo el lector concreta la obra; la dialéctica de los recuerdos y las expectativas en la lectura; la relación estrecha entre el texto y la obra y entre producción y recepción, más una síntesis de la estética de la recepción.

Inmediatamente se aboca a la estética de la participación, tan suya y tan de los artistas y estetas de los sesentas. Con Iser, Sánchez Vázquez juzga insuficiente cualquier crítica inmanentista del arte y la que explica todo por la sociedad, enarbolada por los estetas de la antigua República Democrática Alemana: apelación antihistórica e interpretaciones del arte como reflejo y como creación. La posición de nuestro profesor suma mezcla compleja de circunstancias político-sociales de la emisión y la obra -y su aspecto de texto- como base de la comprensión que evita la crítica absurda o desenfocada.

Sánchez Vázquez recuerda con gran afecto los experimentos de las artes de los sesentas y setentas del siglo xx: el texto que invita a terminarlo, o a darle un sentido, dentro de los sentidos posibles, y la intervención del receptor en la configuración de la obra. Aprovecha para entregar sus pensamientos sobre lo real y virtual en las artes, y qué papel juega el receptor (menguado por supuesto) en las últimas tecnologías computarizadas. Acepta los logros de esta innovación tecnológica y sus enormes limitaciones desde el ángulo 
estético y social, en especial en los tiempos presentes del capitalismo hostil y "salvaje", pero no deja de lado sus potenciales perspectivas en condiciones sociales favorables.

En Cuestiones...discute con Rubert de Ventós la “¿Vuelta al arte simbólico?" y "El diseño y el octubre ruso". Nuestro mentor demanda la socialización de las artes, llevándolas a espacios públicos, ampliándolas a la industria mediante un diseño esmerado, reproduciéndolas y haciéndolas más abiertas o demandantes de la participación con-creativa de sus receptores. Sánchez Vázquez se manifiesta, pues, a favor de un arte público, colectivo, útil, en unas condiciones propicias al desarrollo de las potencialidades creadoras de muchos y no sólo de unos pocos, lo que implica que coincide con las experimentaciones artísticas que se hicieron en el periodo bolchevique, encabezadas por Lunacharsky. Nuestro doctor honoris causa aborda minuciosamente las teorizaciones en materia artística de este último, de Lenin y Trotsky, sus discrepancias con ellos, y hasta los fracasos que padecieron debido a las exigencias perentorias de poner las artes al servicio de la Revolución de Octubre.

En "Socialización o muerte del arte", que aparece también en De la estética de la recepción como "Socialización de la creación o muerte del arte", Sánchez Vázquez reafirma sus brillantes observaciones sobre la hostilidad tendencial del capitalismo a las creativas artes. Replantea la producción, distribución y consumo de éstas. Sobra aclarar, pero aclaro, que se mantiene fiel a su credo de que la vitalidad del campo artístico se incrementaría en un socialismo justo y democrático que, valga la redundancia, socializaría bienes y, en dirección contraria a las organizaciones que nos quieren programar como autómatas, extendería la participación en cualquier tipo de praxis o trabajo creativo.

También Cuestiones... incluye un modesto y parcial recorrido de nuestro filósofo por su trayectoria -siempre enemiga de los intentos filosóficos de prescribir un estilo a las diferentes artes- en los campos de la estética que va de 1961 a 1992. Una crítica: se deja en el tintero muchos de sus escritos porque, admitámoslo, fue sumamente prolífico.

"De la crítica de arte a la crítica del arte" explica la misión de esta actividad. Finalmente, en "Modernidad, vanguardia y postmodernismo" Sánchez Vázquez realiza un inquietante diagnóstico de la crisis social del actual nihilismo postmodernista, o nefasto movimiento neoconservador del modernismo que, "hace aguas por todos lados", favoreciendo, además, un arte trivial que mantiene a la mayoría de la población mundial en su "enajenación y oquedad".

En suma, por si alguien lo dudaba, Adolfo Sánchez Vázquez se mantuvo fiel a sus ideas socializantes, justicialistas, democráticas y liberadoras. Cumplió un poco más de noventa años y, contra aquel dicho del 68, nunca se "momificó": será una personalidad joven, lo que, aunado a su sabiduría, aún lo hace uno de los estetas más destacados internacionalmente, y ejemplo a seguir para los 
estudiantes, "pajarillos libertarios" en frase de Violeta Parra. Hasta siempre maestro. Maestro porque cumplió su promesa de poeta:

Que su voz suba a los montes

y baje a la tierra y truene,

eso pide mi garganta

desde ahora y desde siempre. ${ }^{3}$

Porque como dijo el otro Miguel, Miguel de Unamuno: cuando me creáis más muerto, retumbaré en vuestras manos.

${ }^{3}$ Miguel Hernández, "Vientos del pueblo", en Obras completas. Ed. de Emilio Romero y Andrés Ramón Vázquez, pról. de María García Ifach. Buenos Aires, Losada, 1960 , p. 268. 